\title{
THERAPEUTIC EFFECTS OF ALOPERINE ON THE PULMONARY ARTERIAL HYPERTENSION
}

\author{
SHUANG LI ${ }^{1}$, FUBO ZHOU ${ }^{2}$, JIANJIANG DONG ${ }^{3}$, QI DONG ${ }^{1}$, HAIRONG LUAN ${ }^{1}$, LI LI ${ }^{1}$, \\ YANKUN $\mathrm{HAO}^{1 *}$ \\ ${ }^{I}$ Department of Medical Function, Mudanjiang Medical University, Mudanjiang 157011, People's Republic of China \\ ${ }^{2}$ Department of Pharmacology, Mudanjiang Medical University, Mudanjiang 157011, People's Republic of China \\ ${ }^{3}$ Department of Histology and Embryology, Mudanjiang Medical University, Mudanjiang 157011, People's Republic of China
}

*corresponding author: haoyankunmdjmu@yeah.net

Manuscript received: February 2019

\begin{abstract}
In order to study the therapeutic effect of aloperine (ALO) on the pulmonary arterial hypertension (PAH), 90 male Sprague Dawley (SD) rats were divided into six groups: sham group, $\mathrm{PAH}$ group, $\mathrm{PAH}+25 \mathrm{mg} / \mathrm{kg}$ bw ALO group, $\mathrm{PAH}+50 \mathrm{mg} / \mathrm{kg}$ bw ALO group, PAH $+100 \mathrm{mg} / \mathrm{kg}$ bw ALOgroup, and PAH $+25 \mathrm{mg} / \mathrm{kg}$ bw sildenafil group. The hemodynamic parameters, pulmonary fibrosis, vascular endothelial cell structure, intercellular monocyte chemotactic protein-1 (MCP-1) (adhesion factor-1) and ET-1 (endothelin-1) expression levels, and the expression levels of nuclear factor kappa light chain enhancer of activated B cells (NF-KB), tumour necrosis factor- $\alpha$ (TNF- $\alpha$ ), and interleukin-1 $\beta$ (IL-1 $\beta$ ) pathways were assayed by Western blotting in order to evaluate the influence of ALO on PAH. It was revealed that after the successful establishment of monocrotaline-induced PAH models in rats, rats showed decreased wall thickness of pulmonary arterioles, vascular stenosis, irregular swelling of vascular endothelial cells, proliferation of pulmonary fibrous tissues, disordered arrangement, increased number of MCP-1 and ET-1 cells, and increased expression levels of NF- $\kappa B$, TNF- $\alpha$, and IL-1 $\beta$ pathways. Sildenafil is well known to have protective effects on PAH. According to the achieved results, it can be concluded that ALO also has protective effects on PAH. ALO could improve the development of PAH through the NF- $\mathrm{kB}$ p65 signalling pathway.
\end{abstract}

\section{Rezumat}

Pentru a studia efectul terapeutic al aloperinei (ALO) asupra hipertensiunii arteriale pulmonare (HAP), s-a lucrat pe un număr de 90 de şobolani masculi Sprague Dawley (SD) împărțiți în șase grupuri: grupul martor, grupul HAP, grupul HAP + ALO $25 \mathrm{mg} / \mathrm{kg}$ corp, grupul HPA + ALO $50 \mathrm{mg} / \mathrm{kg}$ corp, grupul HPA + ALO $100 \mathrm{mg} / \mathrm{kg}$ corp şi grupul HAP + sildenafil $25 \mathrm{mg} / \mathrm{kg}$ corp. Au fost analizaşi următorii parametrii: hemodinamici, fibroza pulmonară, structura celulară endotelială vasculară, nivelurile expresiei proteinei chemotactice monocitare 1 (MCP-1) (factor de adeziune-1) și ET-1 (endotelin-1) expresia inductorului de lanț uşor al factorului nuclear kappa (NF-kB), factorul de necroză tumorală- $\alpha$ (TNF- $\alpha$ ) şi interleukina-1 $\beta$ (IL-1 $\beta$ ). S-a constatat că, după stabilirea modelelor de HAP induse de monocrotalină la şobolani, aceștia au prezentat o scădere a grosimii peretelui arterelor pulmonare, stenoză vasculară, gonflarea neregulată a celulelor endoteliale vasculare, proliferarea țesuturilor fibroase pulmonare, creșterea numărului de MCP- 1 și celule ET-1 și niveluri crescute ale factorilor NF-kB, TNF- $\alpha$ și IL-1 $\beta$. Sildenafilul este cunoscut pentru efectele sale protectoare asupra HAP. Conform rezultatelor obținute, se poate concluziona că ALO are și efecte protectoare asupra HAP prin intermediul căii de semnalizare NF-kB p65.

Keywords: aloperine, pulmonary arterial hypertension, monocyte chemotactic protein-1, endothelin-1, NF- $\mathrm{B}$

\section{Introduction}

Pulmonary arterial hypertension (PAH) is a chronic and progressive disease determined by increased blood pressure in the arteries that go from heart to lungs that untreated leads to right heart failure and ultimately, death [1]. Risk factors include family history, prior blood clots in the lungs, human immunodeficiency virus infection and acquired immune deficiency syndrome (HIV/AIDS), sickle cell disease, cocaine use, chronic obstructive pulmonary disease (COPD), sleep apnoea, living at high altitudes, and problems with the mitral valve $[2,28]$. In patients with lung cancer, pulmonary hypertension can be produced by the immune and inflammatory process triggered by cancer cells. The alternative natural therapies with the cytotoxic effect such as alpha lipoic acid and Pistacia lentiscus were tried and the therapeutic effects were promising $[3,4]$. Because of the remodelling of pulmonary arterioles and continuous increase of pulmonary vascular resistance caused by PAH, the long-term persistent $\mathrm{PAH}$ increases the right heart load, which may eventually lead to right ventricular dysfunction and even death due to right-sided heart failure $[5,6]$. The leading cause of $\mathrm{PAH}$ is the imbalance of vasodilator and contractile factors caused by inflammatory cell infiltration [7], resulting in proliferation and hypertrophy of pulmonary arterial smooth muscle cells (PASMCs), the release of inflammatory factors, intimal hyperplasia and plexus vascular damage, and thrombosis $[8,9]$. The imbalance 
FARMACIA, 2019, Vol. 67, 4

of vascular endothelial function may be one of the causes of early symptoms of PAH. Inflammation involving various cytokines, such as NF- $\mathrm{BB}$ (nuclear factor kappa-light-chain-enhancer of activated $\mathrm{B}$ cells) and TNF- $\alpha$ (tumour necrosis factor- $\alpha$ ) signalling pathways, is an essential cause of PAH [10]. Modulation of the cytokine signalling pathway and inhibition of inflammatory factors may be a good therapeutic strategy for PAH [11, 12]. Aloperine (ALO) is an alkaloid extracted and isolated from Sophora alopecuroides L, Fabaceae, originally from China. The use of ALO increased in the last years. Many studies showed its anti-inflammatory, anti-oxidative, anti-mutagenic, and immunosuppressive effects [13-16, 29]. It has been speculated that aloperine has a protective effect in PAH, but the mechanisms involved are unclear [17, 18]. Subcutaneous injection of monocrotaline into the abdomen of experimental animals can form typical "inflammatory" PAH and can be used to obtain a suitable PAH murine model [19]. Platelet-derived growth factor (PDGF) is known as a chemical inducer for the occurrence and development of PAH [20]. In this study, we use a murine model of PAH on male Sprague Dawley (SD) rats that received monocrotaline and PDGF-BB by subcutaneous injection into the abdomen. Using this animal model, this study aimed to investigate the protective effect of ALO on PAH and whether these effects are related to the NF- $\kappa B$ p65, TNF- $\alpha$, and interleukin-1 $\beta$ (IL-1 $\beta$ ) pathways. Sildenafil was used in the experiment as a positive control for the validity of the study. Sildenafil is a PDE-5 (phosphodiesterase type-5) inhibitor known for its anti-PAH effects [21].

\section{Materials and Methods}

\section{Animal study}

Ninety male Sprague Dawley (SD) rats (age, 6 - 8 weeks; body weight, 260 - $280 \mathrm{~g}$ ) were purchased from Nanjing Junke Bioengineering Co., Ltd, China. The animals were housed in a controlled environment with $12 \mathrm{~h} \mathrm{light/dark} \mathrm{cycle,} \mathrm{a} \mathrm{temperature} \mathrm{of} 21 \pm 2{ }^{\circ} \mathrm{C}$ and a humidity between $35-55 \%$. The experiments were performed with the approval of the Ethical Committee of Mudanjiang Medical University, China. The animals were randomly divided into six groups, 15 rats per group as follows: A: sham group, B: PAH group, C: PAH + sildenafil (25 $\mathrm{mg} / \mathrm{kg}$ bw) group, $\mathrm{D}: \mathrm{PAH}+\mathrm{ALO}(25 \mathrm{mg} / \mathrm{kg}$ bw) group, E: PAH + ALO $(50 \mathrm{mg} / \mathrm{kg}$ bw) group, F: PAH + ALO (75 mg/kg bw) group.

The PAH groups received $50 \mathrm{mg} / \mathrm{kg}$ bw/day of $2 \%$ monocrotaline (Sigma-Aldrich, USA) solution injected subcutaneously from the first day of the experiment. The sham group received the same volume of saline solution. From the $22^{\text {nd }}$ day of the experiment, the rats from $\mathrm{PAH}+\mathrm{ALO}$ groups received by gavage 25 , 50 , and respectively $100 \mathrm{mg} / \mathrm{kg}$ bw/day ALO (Shanghai
Yuanye Pharmaceutical Factory, China) for 21 days. The rats from $\mathrm{PAH}+$ sildenafil group received by gavage $25 \mathrm{mg} / \mathrm{kg}$ bw/day sildenafil (Hubei Dibai Chemical Co., Ltd. China) for 21 days from the $22^{\text {nd }}$ day of the experiment. The rats from the sham group and the PAH group received the same amount of saline solution for 21 days.

Detection of hemodynamic parameters and right ventricular hypertrophy index (RVHI)

After 42 days from the start of the experiment, all the rats were weighed. Then the animals were anesthetized by intraperitoneal injection of $1 \mathrm{~mL} / 100 \mathrm{~g}, 20 \%$ urethane (Sigma, USA). When the animals reached the deep state of anaesthesia, the pressure transducer filled with heparin (ABCam, USA) was connected with a right cardiac catheter. The air bubbles were expelled upward, and the right cardiac catheter was also filled with heparin solution. Then, the valve between the pressure transducer and the right cardiac catheter was temporarily closed. The rats were fixed on the operating table in the supine position after breathing stabilization. The right posterior longitudinal cut of the neck $(1-2 \mathrm{~cm})$ was sterilized with $75 \%$ alcohol. After removing the connective tissues and mucosa, the right external jugular vein was put back into the tissue for about $1 \mathrm{~min}$. After stripping the right external jugular vein, the connective tissue and mucosa was removed without damaging the blood vessels, and then the right external jugular vein was put back into the tissues for about 1 minute, so as to re-fill the blood vessels. The distal end of the right external jugular vein was ligated. The stable RVSP and mean pulmonary artery pressure (mPAP) in rats were measured by MPA Cardiac Function Analysis System (China Alcott Technology Company, China). At the proximal end of about $50 \mathrm{~mm}$ from the ligation point, a small $\mathrm{V}$ shaped opening was cut to allow the catheter to enter in the right ventricle to measure right ventricle systolic pressure (RVSP). After the waveform was stable for $5 \mathrm{~min}$, the right cardiac catheter was gently pushed into the pulmonary artery to measure mPAP.

After the hemodynamic parameters were measured, the thoracic cavity of rats was opened and washed with pre-cooled saline. The right ventricle and left ventricle were separated and weighed accurately, and the RVHI (right ventricle hypertrophy index) was calculated using the following formula:

\section{$R V H I=$ right ventricular free wall/ left ventricle + interventricular septum.}

Morphological evaluation of pulmonary arterioles After measuring the RVHI, the left upper lobe and right ventricular apex tissues of rats were fixed in $10 \%$ formaldehyde for $48 \mathrm{~h}$, for histological and immunohistochemical studies. After $10 \%$ formaldehyde fixation for $48 \mathrm{~h}$ the tissue was embedded in paraffin, cut into $4 \mu \mathrm{m}$ sections and deparaffinized in xylene. Part of the tissue sections was stained with haematoxylin and 
FARMACIA, 2019, Vol. 67, 4

eosin (H\&E) and examined by transmission electron microscope (TEM) (Zeiss, Germany).

Assessment of the degree of pulmonary arteriolar fibrosis

The dried paraffin slices were stained with Masson's trichrome and examined by transmission electron microscopy (TEM) (Zeiss, Germany). The slices were stained with H\&E, differentiated by hydrochloric acid alcohol, washed by distilled water, and stained with Masson's trichrome (Soleboard Technology Co., Ltd. China). The slides were soaked with $2 \%$ glacial acetic acid (Nanjing Kaiji Corporation, China) and differentiated by $1 \%$ phosphomolybdic acid (Nanjing Kaiji Corporation, China) solution. After staining with aniline blue (ABCam, USA), the slices were soaked with $2 \%$ glacial acetic acid, and then soaked in anhydrous ethanol. After dehydration (twice), the slices were transparent with xylene and finally sealed with neutral gum.

Assessment of endothelial cell damage in pulmonary arterioles

The degree of endothelial cell damage in pulmonary arterioles was observed by TEM (Zeiss, Germany). Pulmonary arterioles endothelial cells were taken and fixed, and samples were prepared for TEM. The samples were washed three times with phosphate buffer solution (PBS) (Nanjing Kaiji Corporation, China) for $10 \mathrm{~min}$ each time. After that, the samples were fixed for $1 \mathrm{~h}$ with $1 \%$ osmium acid fixative (Nanjing Dongrui Platinum Co., Ltd. China) and cleaned with PBS for three times, 10 min each time. Dehydration, osmotic embedding, and polymer-embedding were performed, and the samples were dried in the oven at $45^{\circ} \mathrm{C}$ for $24 \mathrm{~h}$ and at $60^{\circ} \mathrm{C}$ for $48 \mathrm{~h}$. Sections of $60 \mathrm{~nm}$ were cut and observed after dying.

Determination of intercellular MCP-1 (adhesion molecule 1) levels by immunohistochemistry (IHC)

The paraffin-embedded sections were incubated for 2 hours with primary rabbit monoclonal MCP-1 antibody (1:200). The expression level of inflammatory related factors in lung tissue was observed and evaluated under microscope. The images were analysed by Quantity One 4.6.2 Image Analyser (Bio-RAD Company, USA), and the relative expression was obtained. The sections were visualized with DAB kit (Solebo, China) using DAB (3,3'-diaminobenzidine) stain and haematoxylin as counterstain. The expression levels of related inflammatory factors in lung tissues was assessed by TEM.

Determination of intercellular ET-1 (endothelin-1) levels by immunohistochemistry (IHC)

The paraffin-embedded sections were incubated for 2 hours with primary rabbit monoclonal antibody ET-1 (1:1000), followed by incubation for $30 \mathrm{~min}$ with the secondary antibody coupled with horseradish peroxidase (dilution, 1:2000) (Abcam, Cambridge, UK). The number of stained positive cells was observed under a microscope to evaluate the expression of inflammatory-related factors in lung tissue. The sections were visualized with DAB kit (Solebo, China) as previously described.

The expression of $N F-\kappa B$, TNF- $\alpha$, and $I L-1 \beta$ in pulmonary tissues of rats with $P A H$, assessed by Western blotting

The protein extraction was made from lung tissues using bicinchoninic acid (BCA) protein assay kit (ABCam, USA) according to manufacturer instructions. Detection of sample protein content: the extracted protein solution was diluted 20 times by adding $19 \mu \mathrm{L}$ lysis buffer and then $200 \mu \mathrm{L}$ BCA (ABCam, USA) working solution. The conditions of the enzyme labelling instrument were set as follows: incubation at $37^{\circ} \mathrm{C}$ for $30 \mathrm{~min}$, oscillation once every $10 \mathrm{~s}$, and measurement of the optical density (OD) at $562 \mathrm{~nm}$. The samples concentration $(\mu \mathrm{g} / \mu \mathrm{L})$ were obtained according to the standard curve. According to the measured protein concentration, lysis buffer was added in proportion to adjust the protein concentration of the sample to $5 \mu \mathrm{g} / \mu \mathrm{L}$, boiled for $10 \mathrm{~min}$, and then cooled and sub-packed at $-80^{\circ} \mathrm{C}$ to avoid repeated freezing and thawing.

Electrophoresis and transmembrane were carried out after the separation of colloidal particles. After the film was transferred, nitrocellulose (NC) membrane and gel were removed, and $2.5 \mathrm{~g}$ skimmed milk powder was dissolved in $50 \mathrm{~mL}$ PBST to form the 5\% sealing solution, and NC membrane was sealed after $2 \mathrm{~h}$. The immunoblots were washed and then probed with rabbit anti-NF- $\kappa$ B antibody (ABCam, USA) (1:1000), antiTNF- $\alpha$ antibody (ABCam, USA) (1:500), and antiIL-1 $\beta$ antibody (ABCam, USA) (1:500), respectively. Then membranes were rewarmed for $2 \mathrm{~h}$, washed with PBST (phosphate buffered solution) (Beijing Solebo, China) for 3 times, 10 min each time and incubated for $2 \mathrm{~h}$ with the secondary antibody - mix goat antirabbit IgG with $5 \%$ skimmed milk powder solution (ABCam, USA) at a ratio of 1:2000. After the incubation of the secondary antibody, the NC membrane was taken to discard the secondary antibody and washed three times with PBST, 15 min each time. NC was incubated with the reaction liquid for $2 \mathrm{~min}$, and then exposed and developed.

Statistical analysis

SPSS 17.0 software (IBM, Armonk, NY, USA) was used for data analysis. The data were presented as mean \pm standard deviation (SD). Student's T-test was used to compare the mean of two groups of samples, and One-Way Analysis of Variance (ANOVA) was used to compare the differences in samples among the groups. Pearson correlation was used for correlation analysis. $\mathrm{p}<0.05$ indicated that there was significant difference, and $\mathrm{p}<0.01$ indicated that there was rather significant difference. 


\section{Results and Discussion}

Effects of ALO on MPAP in the murine model of PAH It was revealed that $\mathrm{mPAP}$ in each $\mathrm{PAH}$ group (65 $\mathrm{mmHg}$ ) was significantly higher than that in the sham group $(21 \mathrm{mmHg})$ at 42 days after starting the $\mathrm{PAH}$ experimental model $(p<0.01)$. Compared with the $\mathrm{PAH}$ group, after treatment with different doses of ALO and sildenafil, mPAP decreased to varying degrees, and the mPAP (D: $61 \mathrm{mmHg}$; E: $47 \mathrm{mmHg}$; $\mathrm{F}: 42 \mathrm{mmHg}$ ) in the three PAH + ALO groups (ALO dosage of $25 \mathrm{mg} / \mathrm{kg}, 50 \mathrm{mg} / \mathrm{kg}$ and $100 \mathrm{mg} / \mathrm{kg}$, respectively) was inversely proportional to the ALO dose administered $(\mathrm{p}<0.01)$ (Figure 1A). The percentage of mPAP in the PAH group was 3 times higher than that in the sham group $(\mathrm{p}<0.01)$. It was found that for the other groups with successful modelling, the percentage of LO in the D, E and F groups decreased with the increase of dose, with significant statistical difference $(\mathrm{p}<0.01$ (Figure 1B).

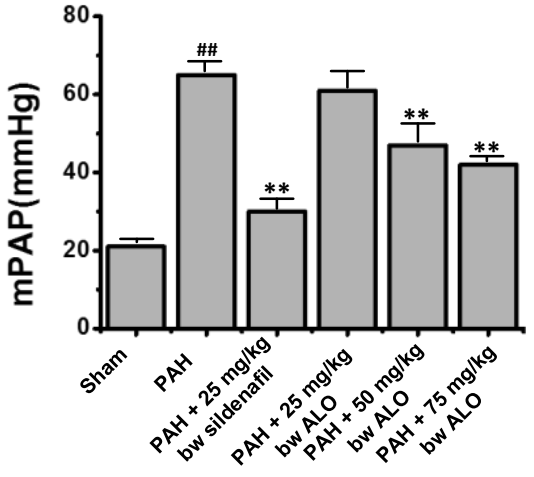

A

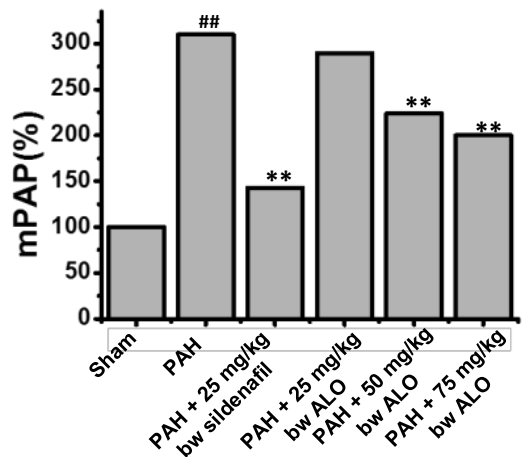

B

Figure 1.

Average pulmonary artery blood pressure of rats in each group: A: Average pulmonary artery blood pressure of rats in each group; B: Percentage change of average pulmonary artery blood pressure of rats in each group

${ }^{\#} \mathrm{p}<0.01$ compared with the sham group; ${ }^{*} \mathrm{p}<0.05,{ }^{* *} \mathrm{p}<0.01$ compared with the PAH group

Effects of ALO on RVSP in the murine model of PAH Right ventricular systolic blood pressure (RVSP) increased significantly $(125 \mathrm{mmHg})$ at 42 days after modelling in $\mathrm{PAH}$ group compared with the sham group $(35 \mathrm{mmHg})(\mathrm{p}<0.01)$. Compared with the PAH group, RVSP decreased in varying degrees after treatment with different doses of ALO and sildenafil, and RVSP (D: $110 \mathrm{mmHg}$, E: $80 \mathrm{mmHg}$, F: $70 \mathrm{mmHg}$ ) of the ALO treatment group (ALO dose of $25 \mathrm{mg} / \mathrm{kg}$, $50 \mathrm{mg} / \mathrm{kg}$ and $100 \mathrm{mg} / \mathrm{kg}$ in groups $\mathrm{D}, \mathrm{E}$, and $\mathrm{F}$, respectively) was inversely proportional to the therapeutic dose. The higher the dosage of ALO, the lower the RVSP ( $p<0.01$ ), as shown in Figure 2A. It was found that the percentage of RVSP in PAH group was 3 times higher than that in sham group $(\mathrm{p}<0.01)$. It was also found that in other groups with successful modelling, the percentage decreased with the increase in the dosage of ALO $(25 \mathrm{mg} / \mathrm{kg}, 50 \mathrm{mg} / \mathrm{kg}, 100 \mathrm{mg} / \mathrm{kg}$, respectively) in $\mathrm{D}, \mathrm{E}$ and $\mathrm{F}$ groups, with significant statistical difference $(\mathrm{p}<0.01)$, as shown in Figure 2B.

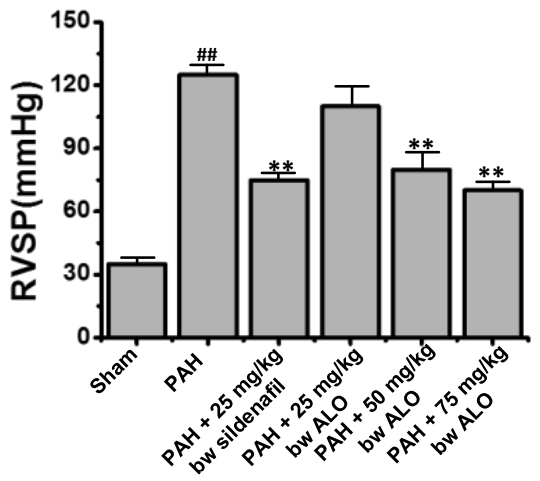

A

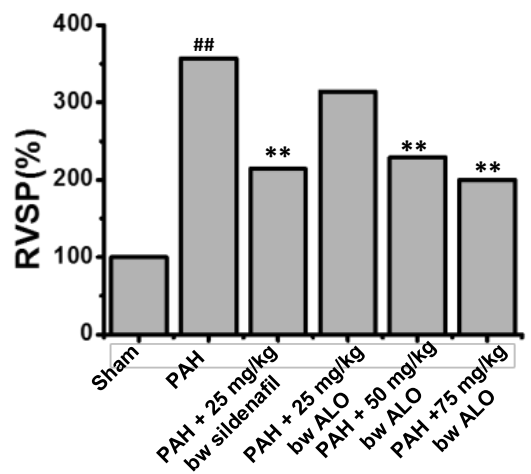

B

Figure 2.

RVSP analysis of rats in each group: A: systolic pressure value of right ventricle of rats in each group; B: percentage change of systolic pressure of right ventricle of rats in each group ${ }^{\#} \mathrm{p}<0.01$ compared with the sham group; ${ }^{*} \mathrm{p}<0.05,{ }^{* *} \mathrm{p}<0.01$ compared with the PAH group 
FARMACIA, 2019, Vol. 67, 4

Effects of ALO on RVHI in the murine model of PAH RVHI increased significantly at 42 days in all PAH groups (0.8) compared with the sham group $(0.3)$ ( $\mathrm{p}<$ 0.01 ). After treatment with ALO and sildenafil the RVHI decreased in varying degrees compare to PAH group. RVHI (D: 0.75, E: 0.65, F: 0.53) of ALO treatment groups (ALO dose of $25 \mathrm{mg} / \mathrm{kg}, 50 \mathrm{mg} / \mathrm{kg}$ and $100 \mathrm{mg} / \mathrm{kg}$, respectively) was inversely proportional to the treatment dose. The higher the dosage of ALO, the lower the RVHI $(\mathrm{p}<0.01)$, as shown in Figure 3A. The percentage of RVHI in the PAH group was 3 times higher than that in the sham group $(p<0.01)$. It was also found that for the other groups with successful modelling, the percentage of ALO in group D, E and $\mathrm{F}(25 \mathrm{mg} / \mathrm{kg}, 50 \mathrm{mg} / \mathrm{kg}$ and $100 \mathrm{mg} / \mathrm{kg}$, respectively) decreased with the increase of dosage, with statistical difference $(\mathrm{p}<0.05)$, as shown in Figure 3B.

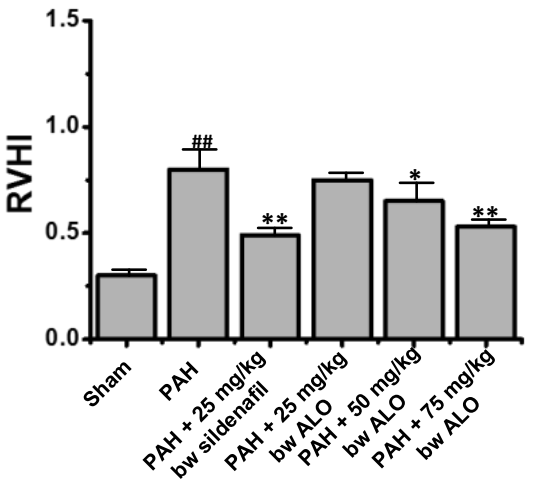

A

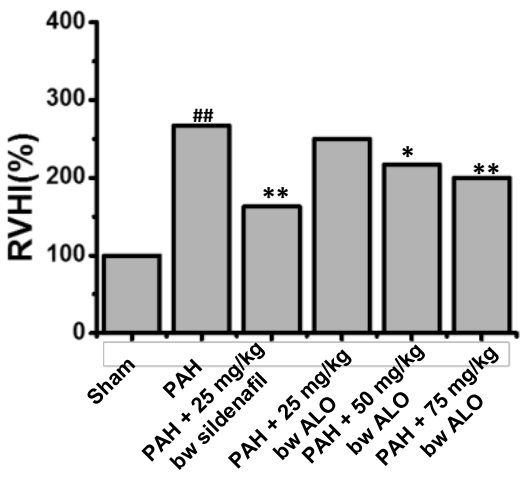

B

Figure 3.

Analysis of RCHI of rats in each group: A: Value of RCHI of rats in each group; B: Percentage change of RCHI of rats in each group

${ }^{\#} \mathrm{p}<0.01$ compared with the sham group; ${ }^{*} \mathrm{p}<0.05,{ }^{* *} \mathrm{p}<0.01$ compared with the PAH group
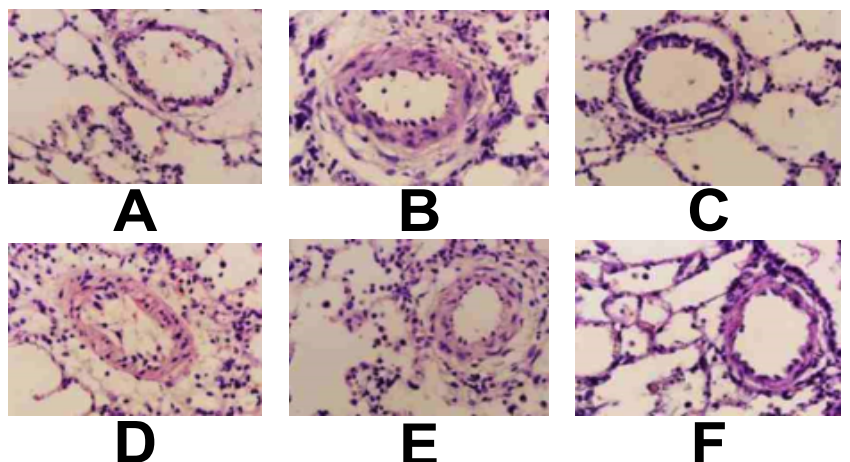

E

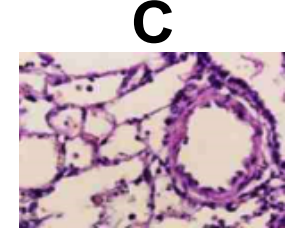

F

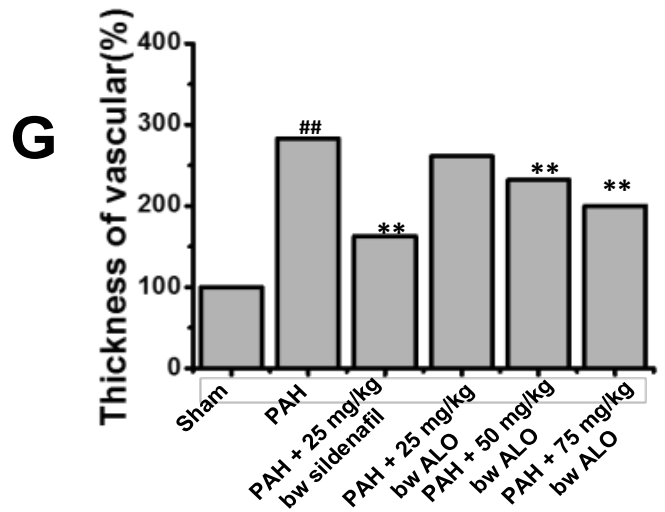

Figure 4.

Light microscopy of pulmonary arterioles in the experimental groups using H\&E staining (magnification x1600):

A: sham group; B: PAH group; C: PAH $+25 \mathrm{mg} / \mathrm{kg}$ bw ALO group; D: PAH $+50 \mathrm{mg} / \mathrm{kg}$ bw ALO group;

$\mathrm{E}: \mathrm{PAH}+75 \mathrm{mg} / \mathrm{kg}$ bw ALO group; F: PAH $+25 \mathrm{mg} / \mathrm{kg}$ bw sildenafil group; G: Percentage of vascular thickness change in rats of each group

${ }^{\#} \mathrm{p}<0.01$ compared with the sham group; ${ }^{*} \mathrm{p}<0.05,{ }^{*} \mathrm{p}<0.01$ compared with the PAH group 
FARMACIA, 2019, Vol. 67, 4

Effects of ALO on vascular remodelling of pulmonary arterioles in the murine model of $P A H$

The results of H\&E staining showed that the endothelial cells of pulmonary arterioles in the sham group $(100 \%)$ were regular in shape, continuous in distribution, and orderly in the arrangement. The endothelial cells of pulmonary arterioles in the model group were partly swollen and exfoliated. PASMCs significantly proliferated with hypertrophy and irregular thickening (283\%) of the lumen, resulting in lumen stenosis or even occlusion $(p<0.01)$. After treatment with ALO and sildenafil, the pulmonary arterial wall thickness of the rats varied between the sham group and the PAH group (The percentage of vascular thickness in group C, D, E and F were $163 \%, 261 \%, 232 \%$ and $200 \%$, respectively), the endothelial cells partially fell off, and PASMCs also showed significant proliferation, while the degree was less than that of the sham group $(\mathrm{p}<0.01)$, as displayed in Figure 4.
Effects of ALO on myocardial tissues in the murine model of $P A H$

According to the H\&E staining results of myocardial tissue sections of rats under light microscopy, compared with the sham group $(100 \%)$, the right ventricular myocardial fibres in the PAH group were disorderly arranged, and the intercellular spaces were enlarged and appeared with an irregular shape. During the sampling process, it was revealed that some rats even died due to pleural effusion, peritoneal effusion, liver enlargement, and severe symptoms $(186 \%)(p<0.01)$. After treatment with ALO and sildenafil, myocardial cells tended to arrange neatly (The percentage of nuclear density of cardiac myocytes in group C, D, E and $\mathrm{F}$ was $142 \%, 173 \%, 164 \%$ and $143 \%$, respectively), with clear edges and regular morphology $(p<0.01)$, as illustrated in Figure 5.
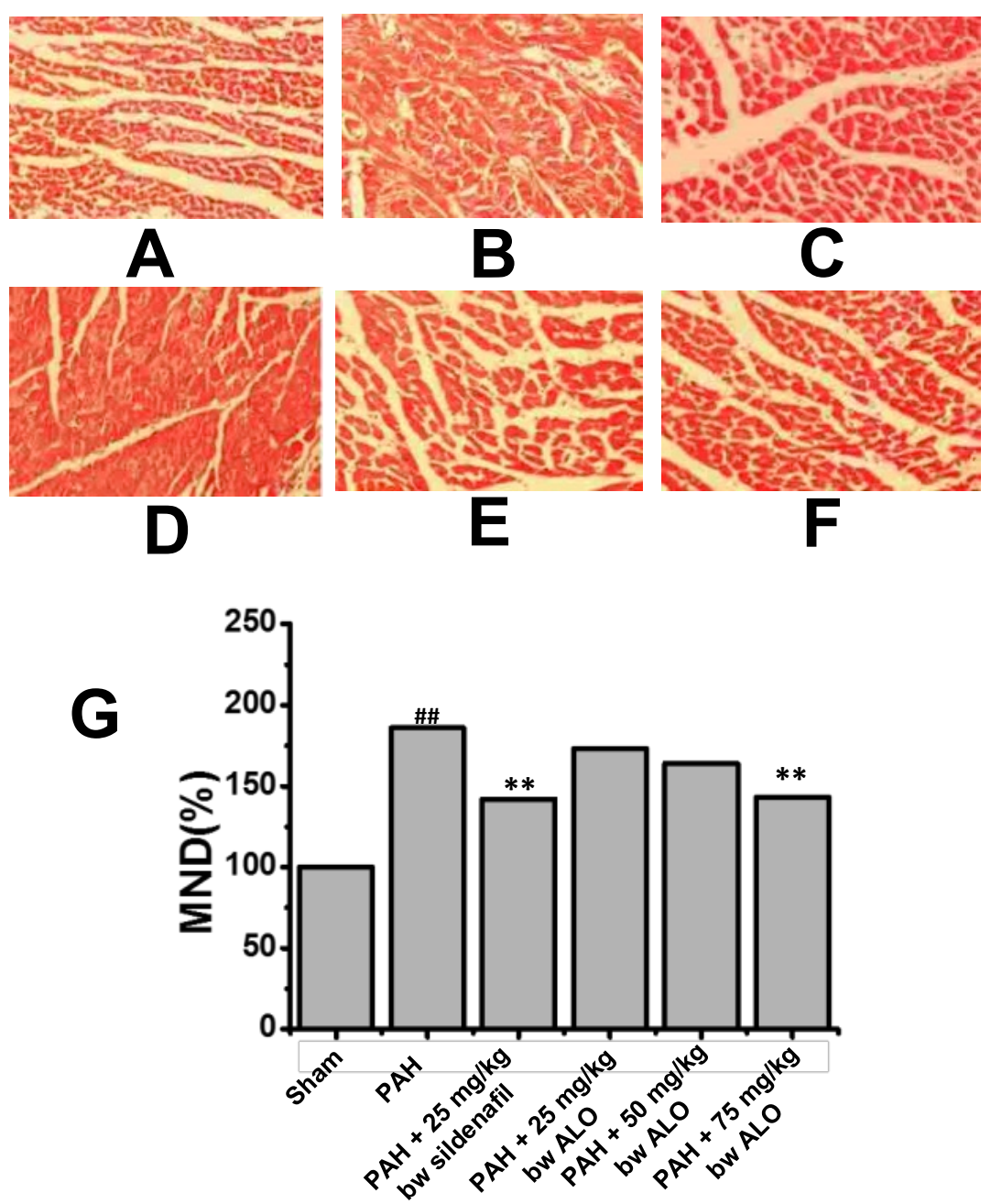

Figure 5.

Myocardial tissue sections in the experimental groups using H\&E staining (magnification $\mathrm{x} 400$ ): A: sham group; B - PAH group; C: PAH + 25 mg/kg bw ALO group; D: PAH + 50 mg/kg bw ALO group; E: PAH + 75 mg/kg bw ALO group; F: PAH $+25 \mathrm{mg} / \mathrm{kg}$ bw sildenafil group; G: Percentage of nuclear density changes in myocardial cells of rats in each group

${ }^{\#} \mathrm{p}<0.01$ compared with the sham group; ${ }^{*} \mathrm{p}<0.05,{ }^{*} \mathrm{p}<0.01$ compared with the PAH group 
Effects of ALO on pulmonary fibrous tissues in the murine model of $P A H$

Masson's trichrome staining of pulmonary fibrous tissue in the PAH group showed that the fibrous muscle and cellulose were red, and the collagen fibres were light pink. In the sham group (100\%), the pulmonary fibrous tissue was well organized, arranged regularly, with normal morphology and visible, alveolar structure. In the PAH group, a great number of collagen fibres could be observed in the pulmonary fibrous tissues. The fibrous structure was disordered, irregularly arranged, and the alveoli were atrophied and blocked $(196 \%)(p<0.01)$. After administration of ALO and sildenafil, the proliferation was markedly improved (The percentage of collagen fibres proliferation in group C, D, E and F were 163\%, 184\%, 176\% and $152 \%$, respectively $(\mathrm{p}<0.01)$, as depicted in Figure 6.
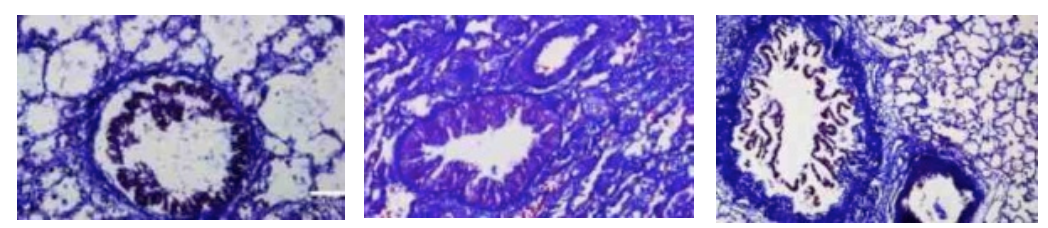

A

B

C
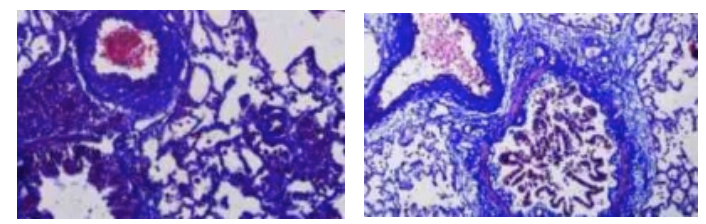

D

E

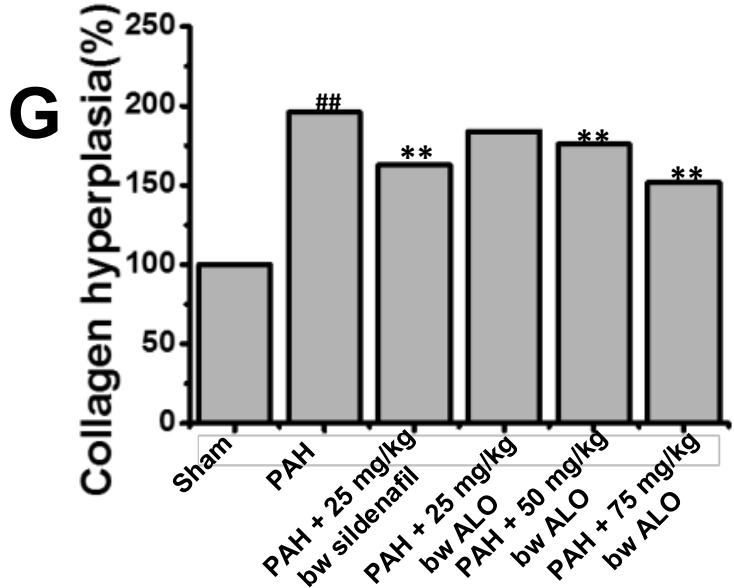

Figure 6.

Light microscopy of pulmonary fibrous tissues in the experimental groups using Masson's trichrome staining (magnification x1600): A: sham group; B: PAH group; C: PAH +25 mg/kg bw ALO group; D: PAH +50 mg/kg bw ALO group; E: PAH + 75 mg/kg bw ALO group; F: PAH + 25 mg/kg bw sildenafil group; G: Percentage

change of collagen fibers proliferation in rats of each group

${ }^{\#} \mathrm{p}<0.01$ compared with the sham group; ${ }^{*} \mathrm{p}<0.05,{ }^{*} \mathrm{p}<0.01$ compared with the PAH group

Effects of ALO on pulmonary vascular endothelial cells in the murine model of PAH

The results of TEM showed that the pulmonary vascular endothelial cells in the sham group (100\%) were arranged regularly, the edge of the nucleus was smooth, and the morphology and quantity of organelles were normal. Compared with the sham group, the number of organelles, including endoplasmic reticulum and Golgi body (179\%), increased, with morphological swelling and expansion. Some of them protruded into the lumen of pulmonary vessels, accompanied by a great number of proliferated collagen fibres, which were arranged disorderly, with statistical difference $(\mathrm{p}<0.01)$. After treatment with ALO and sildenafil (The percentage of organelle changes in group $\mathrm{C}$ and F were $158 \%$ and $132 \%$, respectively $(p<0.01)$, the damage of endothelial cells started alleviate, the number of organelles was reduced, and the shape of the endothelial cell nucleus was normal. Moreover, the cytoplasm was notably decreased, and the vacuoles were less in the endothelial cells than those in the PAH group, as shown in Figure 7. 

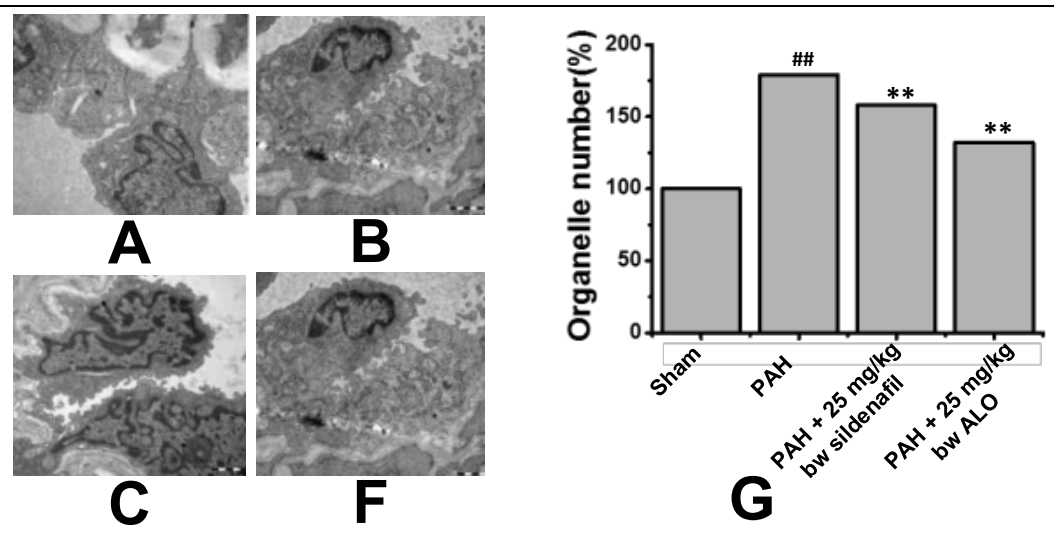

Figure 7.

Pulmonary vascular endothelial cells in the experimental groups: A: sham group; B: PAH group; C: PAH +25 $\mathrm{mg} / \mathrm{kg}$ bw ALO group; F: PAH $+25 \mathrm{mg} / \mathrm{kg}$ bw sildenafil group; $\mathrm{G}$ : Percentage of changes in the number of organelles in endothelial cells of rats in each group

${ }^{\#} \mathrm{p}<0.01$ compared with the sham group; ${ }^{*} \mathrm{p}<0.05,{ }^{* *} \mathrm{p}<0.01$ compared with the PAH group

Effects of ALO on the expression of MCP-1 and ET-1 in pulmonary tissues of rats with pulmonary hypertension

The IHC analysis for MCP-1 and ET-1 expression in the lung tissues evaluated the levels of inflammatory factors in pulmonary vascular endothelial cells. The expression of MCP-1 in pulmonary tissues of rats in pulmonary hypertension group was higher than that in sham group $(192 \%, \mathrm{p}<0.01)$, but the expression of MCP-1 decreased significantly $(143 \%, \mathrm{p}<0.01)$ after administering high dose of ALO $(75 \mathrm{mg} / \mathrm{kg})$; the expression of ET-1 in pulmonary tissues of pulmonary hypertension group was significantly higher than that in sham group $(187 \%, \mathrm{p}<0.01)$. After treatment with high dose of ALO (75 mg/kg), ET-1 expression in pulmonary tissue of pulmonary hypertension rats decreased significantly $(136 \%, 0<0.01)$, as shown in Figure 8.
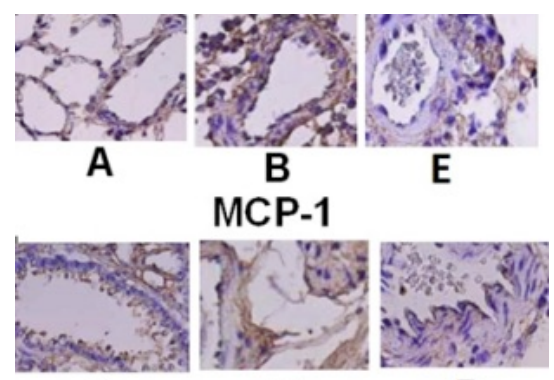

A

B

E

ET-1
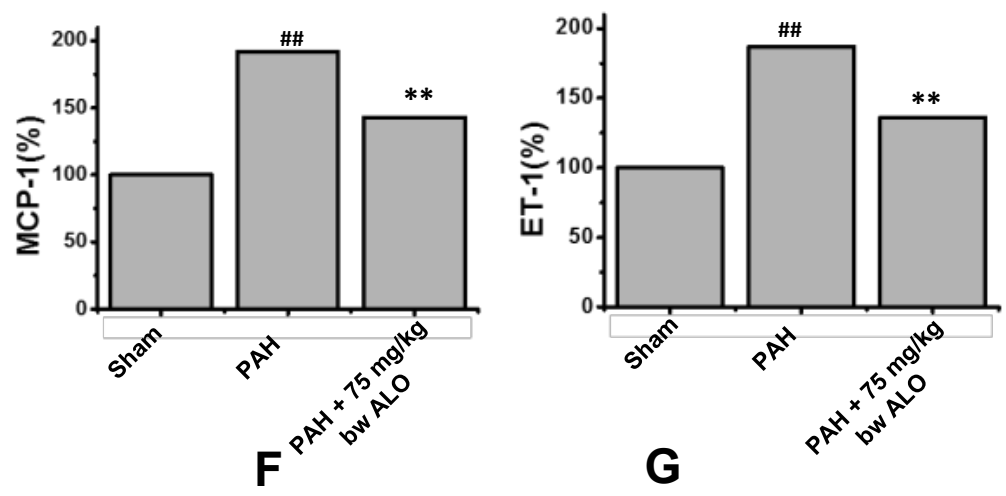

Figure 8.

Expressions of MCP-1 and ET-1 in lung tissues in the experimental groups (magnification x1600): A: sham group; B: PAH group; E: PAH + $75 \mathrm{mg} / \mathrm{kg}$ bw ALO group; F: Percentage change of MCP-1 expression in rats of each group; G: Percentage change of ET-1 expression in rats of each group ${ }^{\#} \mathrm{p}<0.01$ compared with the sham group; ${ }^{*} \mathrm{p}<0.05,{ }^{* *} \mathrm{p}<0.01$ compared with the PAH group 
FARMACIA, 2019, Vol. 67, 4

Effects of $A L O$ on the expression of $N F-\kappa B$ p65, $T N F-\alpha$, and IL-1 $\beta$ in pulmonary tissues

Western blot analysis showed that the expression levels of NF- $k B$ p65, TNF- $\alpha$, and IL- $1 \beta$ in PAH groups were significantly increased compared with those in the sham group. After treatment with $100 \mathrm{mg} / \mathrm{kg}$ bw ALO the expression levels of NF- $\mathrm{BB}$ p65, TNF- $\alpha$, and IL- $1 \beta$ were significantly lower than those of the PAH group, as shown in Figure 9.
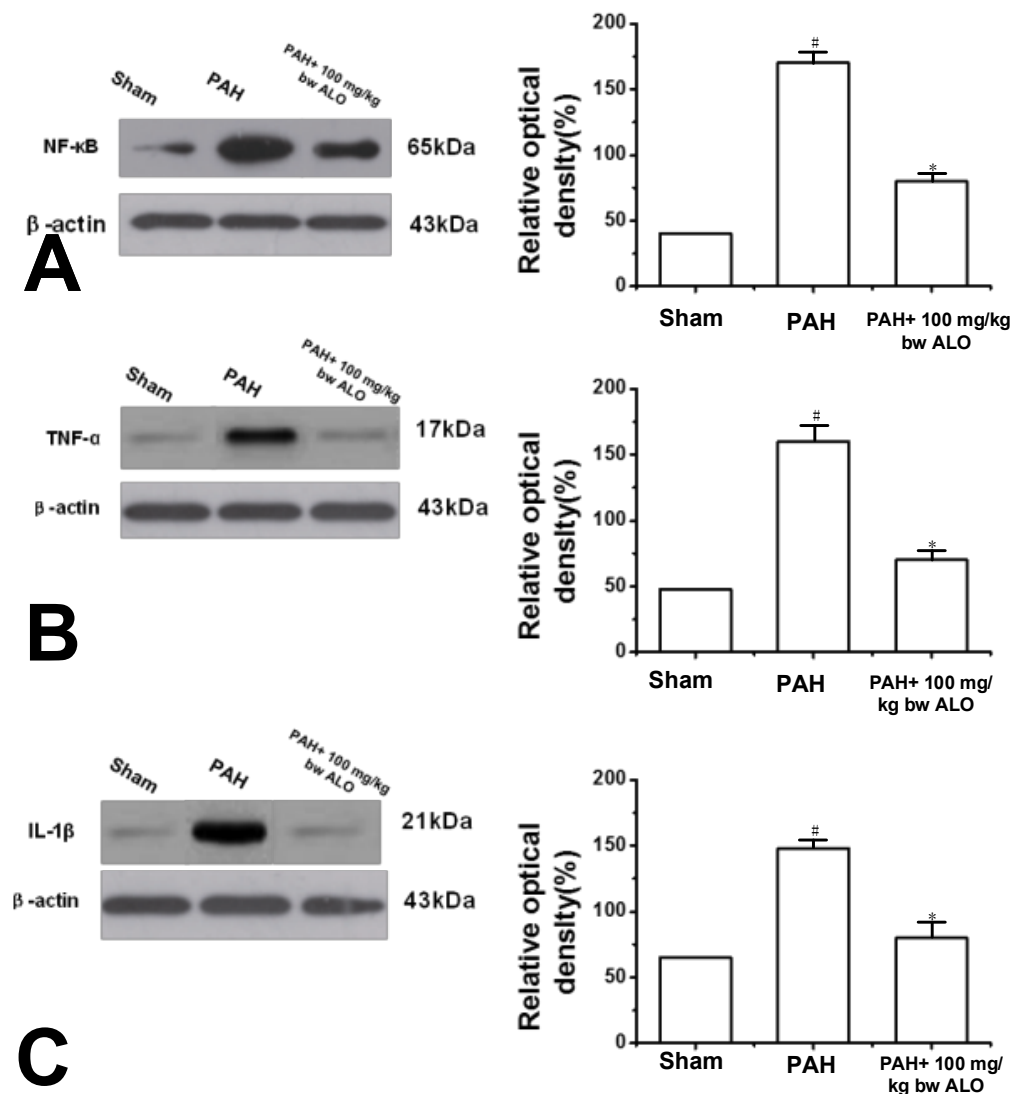

Figure 9.

Western blotting for detecting the expression levels of A: NF- $\mathrm{KB}$ protein; B: TNF- $\alpha$; and C: IL-1 $\beta$ ${ }^{\#} \mathrm{p}<0.05$ compared with the sham group; ${ }^{*} \mathrm{p}<0.05$, compared with the PAH group

PAH is still regarded as a critical disease because of its high mortality and disability rates [22]. There are several methods to successfully induce the establishment of experimental animal models of PAH, including single factor induction models [23], mixed factor induction models [24], and genetic engineering to establish PAH models [25]. The model of monocrotalineinduced PAH in our experiment belongs to the singlefactor model. The model of rats established by this method is relatively stable and can reproduce several models of PAH without a statistical difference, avoiding the interference of other factors [26]. Wu et al. started from the knowledge that pulmonary hypertension is a serious and fatal disease caused by oxidative stress and investigated if the protective effects of ALO in $\mathrm{PAH}$ are related to oxidative stress modulation. The hemodynamic, pathomorphology, electrocardiogram, echocardiography and biomarkers of oxidative stress in rat lung tissues were measured. They found that ALO treatment could alleviate the changes of biomarkers of oxidative stress in rats [27].
In the current study, the progressive increase of PAP caused a significant increase in pressure load in the right ventricle in a short time, which promoted the occurrence of right ventricular hypertrophy and rightsided heart failure. Severe symptoms of death were found in some rats, such as pleural effusion, peritoneal effusion, and liver enlargement caused by severe heart failure. The staining of pulmonary arterioles, pulmonary fibrous tissues and pulmonary vascular endothelial cells in rats with PAH showed that a great number of pulmonary arteriolar endothelial cells were damaged, which resulted in irreversible damage of vascular endothelium and disorderly distribution of pulmonary fibrosis. By detecting the expression levels of MCP-1 and ET-1 in pulmonary tissues of rats with $\mathrm{PAH}$, it was found that the expression levels of MCP-1 and ET-1 were positively correlated with the severity of PAH $(p<0.01)$, and the levels of various inflammatory substances in serum were increased, suggesting that inflammatory factors play a substantial role in PAH. These problems have been improved after the treatment 
FARMACIA, 2019, Vol. 67, 4

with ALO, suggesting that ALO can improve the hemodynamic parameters, such as mPAP and RVSP in monocrotaline-induced PAH rats, protect vascular endothelial cells, and reverse the remodelling of pulmonary arterioles. It can also reduce the right heart load, alleviate the symptoms of right ventricular hypertrophy, and reduce the diameter and nucleus density of myocardial cells. By inhibiting the overexpression of inflammatory factors in lung tissues, monocrotaline-induced PAH in rats was inhibited.

\section{Conclusions}

In this study, rats were taken as the research object, and the effects of ALO on monocrotaline-induced pulmonary hypertension were verified through related experiments, in order to provide experimental basis for the treatment of pulmonary hypertension in later clinical stage. However, there are some shortcomings in the experiment that it was only carried out in rats, but not in human pulmonary artery smooth muscle cells. It was not clear whether ALO had the same improvement effect on human pulmonary hypertension. Therefore, in the follow-up study, in-depth research will be carried out to provide new ideas for the later clinical study of human pulmonary hypertension.

\section{Acknowledgement}

This work was supported by Mudanjiang Science and Technology Planning Project (Z2018s043); The Scientific research projects of basic scientific research in colleges and universities operating expenses of Heilongjiang Province in 2018, China (Grant No. 2018-KYYWFMY-0014).

\section{Conflicts of interest}

The authors declare no conflict of interest.

\section{References}

1. Zhu S, Wang J, Wang X, Zhao J, Protection against monocrotaline-induced pulmonary arterial hypertension and caveolin-1 downregulation by fluvastatin in rats. Mol Med Rep., 2018; 17(3): 3944-3950.

2. Kanwar M, Raina A, Lohmueller L, Kraisangka J, Benza R, The use of risk assessment tools and prognostic scores in managing patients with pulmonary arterial hypertension. Curr Hypertens Rep., 2019; 21(6): 1-15.

3. Mohamed K, Zine K, Fahima K, Abdelfattah E, Sharifudin SM, Duduku K, NiO nanoparticles induce cytotoxicity mediated through ROS generation and impairing the antioxidant defense in the human lung epithelial cells (A549): Preventive effect of Pistacia lentiscus essential oil. Toxicol Rep., 2018;5:480-488.

4. Guzel EE, Kaya N, Ozan G, Tektemur A, Dabak DO, Ozan IE, The investigation of effect of alpha lipoic acid against damage on neonatal rat lung to maternal tobacco smoke exposure. Toxicol Rep., 2018; 5: 714722 .
5. Zhou Y, Wang Y, Wang X, Tian X, Zhang S, Yang F, The protective effects of $\kappa$-opioid receptor stimulation in hypoxic pulmonary hypertension involve inhibition of autophagy through the AMPK-MTOR pathway. Cell Physiol Biochem., 2017; 44(5): 1965-1979.

6. Avouac J, Konstantinova I, Guignabert C, Pezet S, Sadoine J, Guilbert T, Pan-PPAR agonist IVA337 is effective in experimental lung fibrosis and pulmonary hypertension. Ann Rheum Dis., 2017; 76(11): 19311940.

7. Liu A, Philip J, Vinnakota KC, Francoise VDB, Tabima DM, Hacker T, Estrogen maintains mitochondrial content and function in the right ventricle of rats with pulmonary hypertension. Physiol Rep., 2017; 5(6): $1-12$.

8. Bohnen MS, Roman-Campos D, Terrenoire C, Jnani J, Sampson KJ, Chung WK, Kass RS, The impact of heterozygouskcnk3mutations associated with pulmonary arterial hypertension on channel function and pharmacological recovery. J Am Heart Assoc., 2017; 6(9): 1-31.

9. Buchbinder D, Montealegre Sanchez GA, GoldbachMansky R, Brunner H, Shulman AI, Rash, fever, and pulmonary hypertension in a 6-year-old female. Arthrit Care Res. (Hoboken), 2018; 70(5): 785-790.

10. Rathinasabapathy A, Bryant AJ, Suzuki T, Christy M, Sheila S, Santhi G, rhACE2 therapy modifies bleomycininduced pulmonary hypertension via rescue of vascular remodeling. Front Physiol., 2018; 9: 1-10.

11. Kanwar MK, Survival in pulmonary hypertension: Experiences from a referral center. J Heart Lung Transplant, 2017; 36(9): 938-939.

12. Ghataorhe P, Rhodes CJ, Harbaum L, Attard M, Wharton J, Wilkins MR, Pulmonary arterial hypertension - progress in understanding the disease and prioritizing strategies for drug development. J Intern Med., 2017; 282(2): 129-141.

13. Ren D, Ma W, Guo B, Wang S, Aloperine attenuates hydrogen peroxide-induced injury via anti-apoptotic activity and suppression of the nuclear factor- $\mathrm{\kappa B}$ signaling pathway. Exp Ther Med., 2017; 13(1): 315-320.

14. Yin W, Han J, Zhang Z, Han Z, Wang S, Aloperine protects mice against bleomycin-induced pulmonary fibrosis by attenuating fibroblast proliferation and differentiation. Sci Rep., 2018; 8(1): 1-10.

15. Lee YR, Chen SH, Lin CY, Chao WY, Lim YP, Yu $\mathrm{HI}, \mathrm{Lu} \mathrm{CH}$, In vitro antitumor activity of aloperine on human thyroid cancer cells through caspase-dependent apoptosis. Int J Mol Sci., 2018; 19(1): 1-13.

16. Tian D, Li Y, Li X, Tian Z, Aloperine inhibits proliferation, migration and invasion and induces apoptosis by blocking the Ras signaling pathway in human breast cancer cells. Mol Med Rep., 2018; 18(4): 3699-3710.

17. Amadi VN, Balogun MO, Akinola NO, Adebayo RA, Akintomide AO, Pulmonary hypertension in Nigerian adults with sickle cell anemia. Vasc Health Risk Manag., 2017; 13: 153-160.

18. Wu F, Yao W, Yang J, Zhang M, Xu Y, Hao Y, Yan L, Niu Y, Sun T, Yu J, Zhou R, Protective effects of aloperin on monocroline-induced pulmonary hypertension via regulation of Rho A/Rho kinsase pathway in rats. Biomed Pharmacother., 2017; 95: 1161-1168 
19. Wu XT, Chen YQ, Lu WJ. [Role of pulmonary vein in pulmonary hypertension]. Zhonghua Jie $\mathrm{He} \mathrm{He} \mathrm{Hu}$ Xi Za Zhi, 2017; 40(1): 68-70 (article in Chinese).

20. Kaymaz C, Mutlu B, Küçükoğlu MS, Kaya B, Akdeniz B, Kılıçkıran Avcı, Aksakal E, Akbulut M, Atılgan Arıtürk Z, Sümeyye Güllülü, Aydoğdu Taçoy G, Preliminary results from a nationwide adult cardiology perspective for pulmonary hypertension: RegiStry on clInical outcoMe and sUrvival in pulmonaRy hypertension Groups (SIMURG). Anatol J Cardiol., 2017; 18(4): 242-250.

21. Trottier-Boucher MN, Lapointe A, Malo J, Fournier A, Raboisson MJ, Martin B, Moussa A, Sildenafil for the treatment of pulmonary arterial hypertension in infants with bronchopulmonary dysplasia. Pediatr Cardiol., 2015; 36(6): 1255-1260.

22. Li JF, Zhai ZG, Kuang TG, Liu M, Ma ZH, Li YD, Yang $\mathrm{YH}, \mathrm{A}$ case of pulmonary hypertension due to fistulas between multiple systemic arteries and the right pulmonary artery in an adult discovered for occulted dyspnoea. Heart Lung Circ., 2017; 26(8): e54-e58.

23. Karakus G, Zencirci E, Degirmencioglu A, Güvenc TS, Unal Aksu H, Yildirim A, Easily measurable, noninvasive, and novel finding for pulmonary hypertension: Hypertrophy of the basal segment of septomarginal trabeculation of right ventricle. Echocardiography, 2017; 34(2): 290-295.

24. Badea M, Pătraşcu F, Cerc Korošec R, Bukovec P, Raita M, Chifiriuc MC, Maruţescu L, Bleotu C,
Velescu BȘ, Marinescu D, Uivaroși V, Olar R, Thermal, spectral, magnetic and biologic characterization of new $\mathrm{Ni}(\mathrm{II}), \mathrm{Cu}(\mathrm{II})$ and $\mathrm{Zn}(\mathrm{II})$ complexes with a hexaazamacrocyclic ligand bearing ketopyridine moieties. JTAC, 2014; 118(2): 1183-1193.

25. Sahay S, Melendres-Groves L, Pawar L, Cajigas HR, Pulmonary Vascular Diseases Steering Committee of the American College of Chest Physicians. Pulmonary Hypertension Care Center Network: Improving Care and Outcomes in Pulmonary Hypertension. Chest, 2017; 151(4): 749-754.

26. Marshall JD, Bazan I, Zhang Y, Fares WH, Lee PJ, Mitochondrial dysfunction and pulmonary hypertension: cause, effect, or both. Am J Physiol Lung Cell Mol Physiol., 2018; 314(5): L782-L796.

27. Wu F, Hao Y, Yang J, Yao W, Xu Y, Yan L, Niu Y, Sun T, Yu J, Zhou R, Protective effects of aloperine on monocrotaline-induced pulmonary hypertension in rats. Biomed Pharmacother., 2017; 89: 632-641.

28. Prodan (Pura) G, Leucuța DC, Marc G, Simu H, Nastasă C, Oniga $\mathrm{O}$, The impact of urapidil use in hypertension prehospital emergency intervention. Farmacia, 2017; 65(6): 896-899.

29. Hovaneţ MV, Oprea E, Ancuceanu RV, Duţu LE, Budura EA, Şeremet O, Ancu I, Moroşan E, Wound healing properties of Ziziphus jujuba Mill. leaves. Rom Biotech Lett., 2016; 21(5): 11842-11849. 